\title{
Deteksi Senyum Menggunakan Fitur Gabor dan Histograms of Oriented Gradients pada Bagian Mulut, Hidung, dan Mata
}

\author{
Berty Chrismartin Lumban Tobing \\ Fakultas Ilmu Komputer \\ Universitas Indonesia \\ Depok \\ berty.chrismartin@ui.ac.id
}

\begin{abstract}
Permasalahan pendeteksian senyum sangat penting untuk mendeteksi happy mood. Pendeteksian happy mood dapat digunakan untuk kebutuhan komersial seperti mengukur kesuksesan suatu acara dari banyaknya penonton yang tersenyum sepanjang acara. Selain itu, pendeteksi senyum juga digunakan pada bidang teknologi yaitu smile shooter pada kamera. Pendeteksian senyum pada penelitian-penelitian sebelumnya hanya menggunakan bagian wajah yaitu area mulut dengan berbagai macam cara seperti menggunakan fitur PHOG, EOH, dan perbedaan intensitas piksel. Pada penelitian ini, senyum dideteksi dengan menggunakan fitur Gabor dan Histograms of Oriented Gradients (HOG) pada bagian mulut, hidung, dan mata menggunakan classifier SVM. Penelitian ini menggunakan dataset citra dari GENKI-4K. Tingkat pendeteksian senyum pada penelitian ini mencapai $90.40 \%$. Berbeda dengan penelitian sebelumnya, penelitian ini juga melakukan uji coba terhadap citra yang terdiri dari lebih dari tiga wajah untuk mengukur tingkat kesenangan orang yang berada pada citra tersebut.
\end{abstract}

Keywords—happy mood; deteksi senyum; Fitur Histograms of Oriented Gradients; Fitur Gabor; classifier SVM;

\section{INTRODUCTION}

Ekspresi wajah adalah salah satu elemen terpenting untuk mendeteksi emosi dari seseorang. Senyum yang merupakan bagian dari ekspresi wajah dapat digunakan sebagai pengukur tingkat kesenangan seseorang. Oleh karena itu, permasalahan pendeteksian senyum menjadi bagian yang penting untuk mendeteksi tingkat happy mood seseorang. Saat ini, pendeteksian happy mood ini banyak digunakan untuk kebutuhan komersial yaitu mengukur kesuksesan suatu acara dengan melihat banyaknya penonton yang tersenyum. Selain itu, pendeteksian senyum juga digunakan pada bidang teknologi yaitu dalam kamera canggih terdapat fitur smile shooter yang mengindikasikan kamera akan memotret secara otomatis jika mendeteksi senyum (happy mood). Dengan didasari oleh banyaknya kebutuhan yang melibatkan pendeteksian senyum maka pada penelitian ini kami khusus mengembangkan sistem pendeteksi senyum.

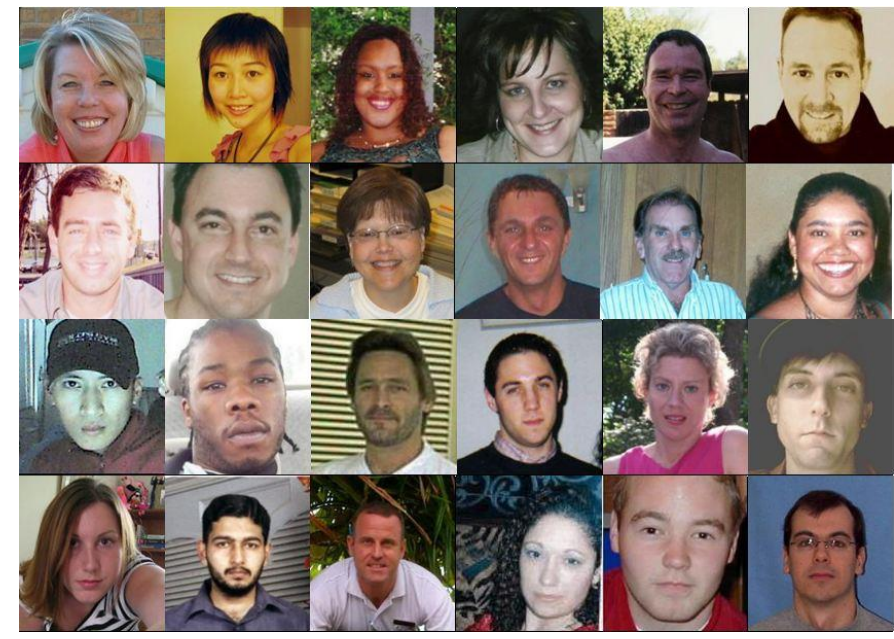

Gambar 1. Contoh dataset GENKI-4K, wajah tersenyum (dua baris teratas), dan tidak tersenyum (dua baris terbawah)

Penelitian ini menggunakan dataset GENKI-4K ${ }^{1}$ Face, Expression, dan Pose Dataset yang terdiri dari 4.000 citra yang disertai dengan label konten senyum ( $1=$ senyum, $0=$ tidak senyum), dan pose dari kepala yang terdiri dari parameter yaw, pitch, dan roll dalam satuan radian. Pada dataset ini, setiap citra terdiri atas satu wajah dan memiliki angle dan background citra yang berbeda-beda. Selain itu, karakteristik orang yang berada dalam citra tersebut berbeda-beda seperti warna kulit dan aksesoris yang dipakai. Banyak penelitian yang menggunakan dataset ini dengan memvariasikan banyaknya data training dan data testing. Pada penelitian ini, penulis mengambil secara acak 1081 citra yang terdiri dari 593 citra dengan label senyum dan 488 citra dengan label tidak senyum. Contoh ekspresi wajah pada GENKI-4K dapat dilihat pada Gambar 1.

Penelitian-penelitian sebelumnya berbagai pendekatan dan berbagai macam fitur telah digunakan untuk mendeteksi senyum seperti fitur Box Filters (BF) [1], Pyramid Histogram of Oriented Gradients (PHOG) [2], dan perbedaan intensitas

\footnotetext{
${ }^{1}$ Dataset dapat diunduh pada http://mplab.ucsd.edu
} 
piksel pada suatu citra [3]. Penelitian [1] menggunakan Box Filters dan berbagai macam fitur lain yang diambil dari keseluruhan wajah dengan pembantu pendeteksi mata secara otomatis dan juga manual untuk memperkirakan posisi dari mulut. Classifier yang digunakan adalah GentleBoost dan Support Vector Machine (SVM). Sedangkan pada penelitian [2] dan [3], keduanya khusus mengekstrak fitur pada bagian sekitar mulut dan menggunakan classifier SVM dan AdaBoost. Pendeteksian senyum dapat ditinjau dari bagian-bagian yang terdapat pada wajah. Namun dapat dilihat bahwa pada penelitian-penelitian sebelumnya, umumnya menggunakan fitur bagian mulut saja.

Pada penelitian ini fitur yang digunakan adalah Gabor dan Histograms of Oriented Gradients (HOG). Berbeda dengan penelitian sebelumnya, penelitian ini khusus mengekstrak fitur pada bagian mulut, hidung, dan mata yang kemudian dilihat seberapa besar pengaruh masing-masing bagian untuk mendeteksi senyum. Pengkombinasian masing-masing bagian juga akan dilihat pengaruhnya terhadap akurasi dalam pendeteksian senyum. Selain itu, penghitungan akurasi yang melibatkan fitur-fitur yang dipakai yaitu Gabor dan HOG juga ditampilkan. Classifier yang digunakan pada penelitian ini adalah SVM dengan fungsi kernel linear.

\section{FITUR GABOR}

Gabor wavelets telah ditemukan dan sangat cocok untuk mendekomposisi dan merepresentasi citra ketika tujuannya adalah untuk derivasi dari fitur lokal dan diskriminatif [8]. Gabor wavelets digunakan untuk menganalisis citra, hal ini dikarenakan oleh relevansi biologis dan sifat komputasinya. Gabor wavelets (kernel, filters) dapat didefinisikan dengan:

$$
\psi_{\mu, v}(z)=\frac{\left\|k_{\mu, v}\right\|^{2}}{\sigma^{2}} e^{-\left(\frac{\left\|k_{\mu, v}\right\|^{2}\|z\|^{2}}{2 \sigma^{2}}\right)}\left[e^{i k_{\mu, v^{z}}}-e^{-\left(\frac{\sigma^{2}}{2}\right)}\right]
$$

Dengan $\mu$ dan v menyatakan orientasi dan skala dari Gabor kernels, $\mathrm{z}=(\mathrm{x}, \mathrm{y}),\|\cdot\|$ menyatakan operator norm, dan vektor gelombang $\mathrm{k}_{\mu, \mathrm{v}}$ dinyatakan sebagai berikut:

$$
k_{\mu, v}=k_{v} e^{i \phi_{\mu}}
$$

Dimana $\mathrm{k}_{\mathrm{v}}=\mathrm{k}_{\max } / \mathrm{f}^{\mathrm{v}}$ dan $\phi_{\mu}=\pi \mu / 8 . \mathrm{F}$ merupakan faktor jarak antara kernels dalam domain frekuensi [8].

Representasi Gabor wavelet dari suatu citra merupakan hasil konvolusi dari citra dengan keluarga Gabor kernel sebagaimana didefinisikan pada (1). Representasi Gabor yang digunakan adalah dengan menggunakan lima spasial dan delapan orientasi seperti yang biasa digunakan ketika mengekstrak Gabor fitur dari citra wajah [8].

Contoh hasil proses ekstraksi dari suatu citra wajah menggunakan fitur Gabor dalam bentuk real part of convolution outputs dan magnitude of the convolution outputs dapat dilihat pada Gambar 2.

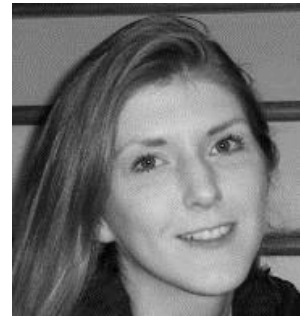

(a)

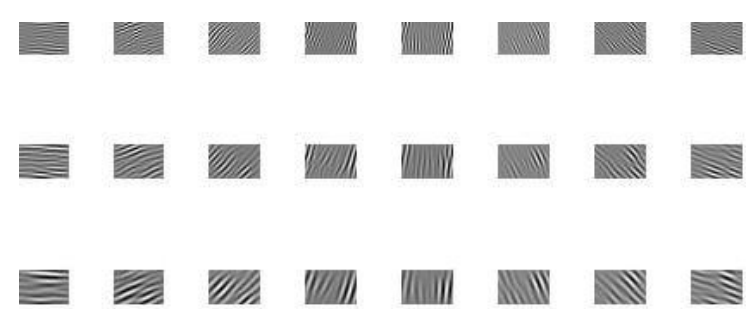

至

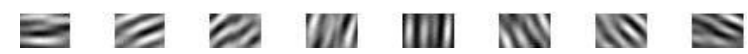
(b)

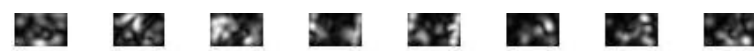

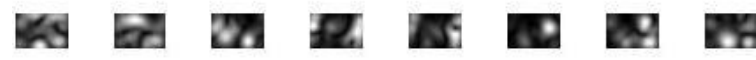

M EA
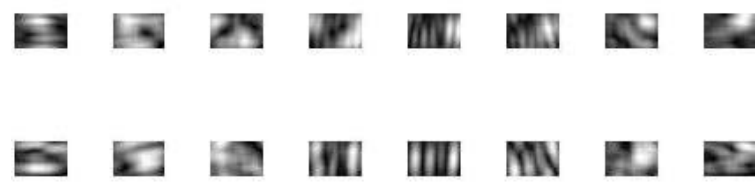

(c)

Gambar 2. (a) Contoh citra wajah, (b) Real part of the convolution outputs dari (a), (c) Magnitude of the convolution outputs dari (a)

\section{FITUR HISTOGRAMS OF ORIENTED GRADIENTS}

Histograms of oriented gradients (HOG) merupakan deskripsi fitur yang digunakan dalam image processing maupun computer vision yang bertujuan untuk mendeteksi suatu objek. HOG dapat secara efektif dan sukses mengekspresikan fitur bentuk dalam pendeteksian manusia [5]. Teknik yang digunakan pada HOG adalah menghitung kemunculan orientasi gradien dalam porsi lokal dari suatu citra. Dengan ciri tersebut, HOG dapat dikatakan mirip seperti Edge Orientation Histograms (EOH). 


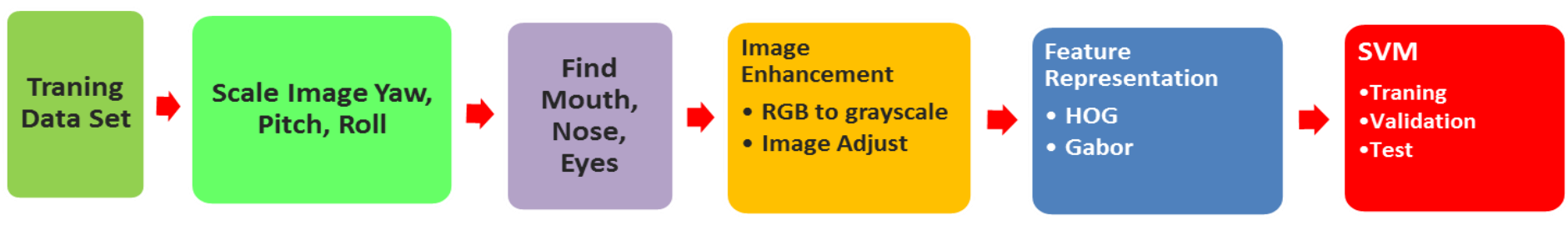

Gambar 3. Flowchart Sistem Pendeteksi Senyum

Ide dasar dari deskriptor HOG adalah penampilan dan bentuk dari lokal objek dalam suatu citra dapat dideskripsikan oleh distribusi dari intensitas gradien atau arah tepi [7]. Pengimplementasian deskriptor ini dalam dicapai dengan membagi citra ke dalam daerah spasial yang lebih kecil yang disebut sel, dan untuk setiap sel terapkan HOG atau orientasi tepi untuk setiap piksel di dalam sel. Kombinasi dari histogram tersebutlah yang disebut dengan deskriptor. Untuk mendapatkan hasil yang lebih baik, histogram lokal dapat dinormalisasikan tingkat kekontrasannya dengan menghitung ukuran intensitas untuk wilayah yang lebih besar yang disebut blok (lihat Gambar 4). Kemudian gunakan nilai tersebut untuk menormalkan semua sel di dalam blok [7].

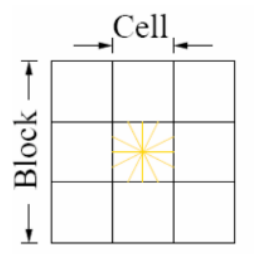

Gambar 4. Sel dan Blok pada HOG

Pengimplementasian HOG umumnya dibagi menjadi empat bagian yaitu:

- Gradient computation: Tahap pertama adalah menghitung nilai gradien dari citra. Pada tahapan ini memerlukan filtering terhadap warna ataupun intensitas data dari citra dengan menggunakan kernel: $[-1,0,1]$ dan $[-1,0,1]^{\mathrm{T}}$.

- Oritentaion binning: Tahap kedua adalah membuat histogram sel. Setiap piksel dalam sel menampung nilai dari histogram orientasi berdasarkan nilai-nilai yang ditemukan dalam perhitungan gradien pada tahap pertama.

- Descriptor blocks: Tahap ketiga membuat deskriptor blok yang menormalisasi gradien secara lokal dalam rangka memperhitungkan perubahan pencahayaan dan kontras pada citra. Sehingga dibutuhkan pengelompokan sel ke dalam bentuk yang lebih besar yaitu blok.
- Block normalization: Tahap terakhir merupakan menormalisasi histogram dan menggabungkan histogram yang telah dinormalisasi menjadi satu vektor. Selanjutnya, nilai dari deskriptor HOG merupakan komponen dari vektor panjang histogram yang telah dinormalisasi dari semua daerah blok yang ada.

Gambar 5 mengilustrasikan penggunaan HOG serta arah gradien dalam suatu citra dengan menggunakan sel sebesar $16 \times 16$ piksel dan blok sebesar 2x2 sel.

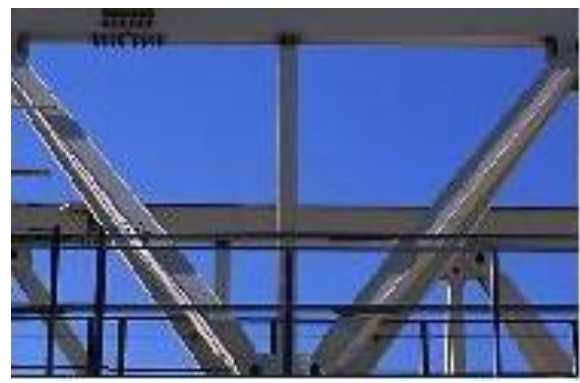

(a)

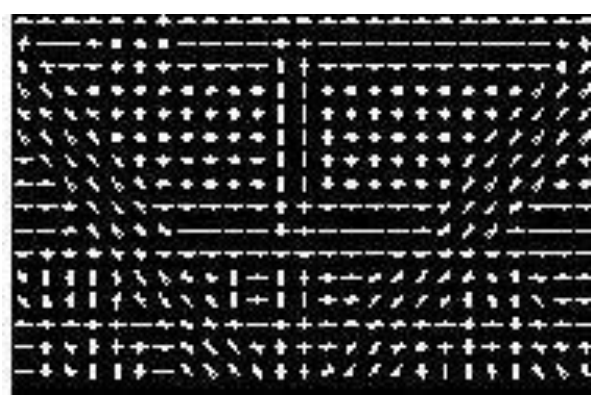

(b)

Gambar 5. (a) Citra jembatan, (b) Penerapan HOG pada citra (a)

\section{METHODS}

Berikut merupakan metode yang dilakukan penulis untuk penelitian ini yang terdiri dari pengumpulan data, environment eksperimen, preprocessing citra, pendekteksian mulut, hidung, dan mata, image enchancement, dan proses klasifikasi. Metode penelitian ditampilkan pada Gambar 3. 


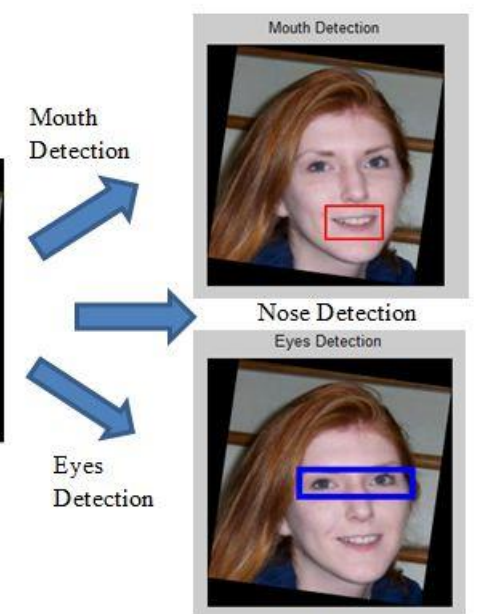

(c)

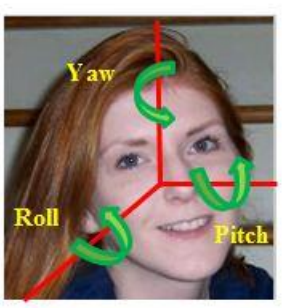

(a)

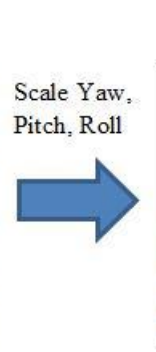

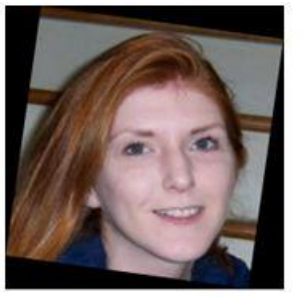

(b)

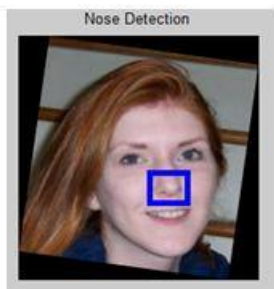

Gambar 6. (a) Preprocessing rotasi yaw, pitch, dan roll, (b) Hasil preprocessing pada bagian (a), (c) Pendeteksian mulut, hidung, dan mata

\section{A. Pengumpulan Data}

Pendeteksian senyum pada penelitian ini menggunakan dataset GENKI-4K dengan memilih secara acak 1081 citra yang terdiri dari 592 citra yang berlabel senyum dan 489 citra yang berlabel tidak senyum. Penggunaan GENKI-4K dikarenakan dataset tersebut umum digunakan dalam penelitian mengenai pendeteksian senyum. Hal ini menunjang penyeragaman dataset. Selain GENKI-4K terdapat dataset khusus untuk pendeteksi senyum lain yaitu Cohn-Kanade DFAT $^{2}$

Pada dataset ini, setiap citra terdiri atas satu wajah dan memiliki angle dan background citra yang berbeda-beda. Selain itu, karakteristik orang yang berada dalam citra tersebut berbeda-beda seperti warna kulit dan aksesoris yang dipakai. Dataset yang dipakai adalah citra dengan ukuran 179x192 piksel (lihat Gambar 1).

Dataset dibagi menjadi 3 bagian yaitu dataset untuk traning, validation, dan testing. Dataset training terdiri dari 500 citra, 250 senyum dan 250 tidak senyum. Dataset testing terdiri dari 250 citra, 140 senyum dan 110 tidak senyum. Sedangkan dataset validation merupakan sisanya yaitu 331 dengan 203 senyum dan 128 tidak senyum. Dataset training merupakan dataset yang digunakan untuk proses pelatihan dan dataset testing digunakan untuk proses pengujian. Berbeda dengan dataset traning dan testing, dataset validation digunakan untuk memvalidasi hasil classifier dari proses training dengan memberikan decision maker. Hal ini digunakan untuk memperbaiki classifier yang sudah dibuat pada tahapan training yang menggunakan kombinasi dari berbagai macam bagian wajah.

\section{B. Environment Eksperimen}

Eksperimen dilakukan menggunakan perangkat lunak Matlab R2013b. Eksperimen dijalankan pada sistem operasi

\footnotetext{
${ }^{2}$ Dataset dapat diunduh di http://www.cs.cmu.edu/
}

Windows 764 bit dengan RAM sebesar 4 GB dan prosesor Intel Core i7 $2.10 \mathrm{GHz}$.

\section{Preprocessing Citra}

Sebelum citra diekstraksi, mulanya dilakukan preprocessing terlebih dahulu. Tahapan preprocessing ini dengan melakukan rotasi citra menggunakan yaw, pitch, dan roll. Perotasian ketiga elemen tersebut dalam satuan radian seperti yang disediakan dataset GENKI-4K. Masing-masing matriks rotasi untuk yaw, pitch, dan roll adalah sebagai berikut:

$$
\begin{aligned}
& \operatorname{yaw}(x)=\left(\begin{array}{ccc}
\cos x & -\sin x & 0 \\
\sin x & \cos x & 0 \\
0 & 0 & 1
\end{array}\right) \\
& \operatorname{pitch}(x)=\left(\begin{array}{ccc}
\cos x & 0 & \sin x \\
0 & 1 & 0 \\
-\sin x & 0 & \cos x
\end{array}\right) \\
& \operatorname{roll}(x)=\left(\begin{array}{ccc}
1 & 0 & 0 \\
0 & \cos x & -\sin x \\
0 & \sin x & \cos x
\end{array}\right)
\end{aligned}
$$

Perhatikan Gambar 6 bagian (a) dan (b) merupakan proses preprocessing menggunakan elemen yaw, pitch, dan roll. Hal ini dilakukan untuk menormalisasi semua citra yang angle wajah sebelumnya tidak tegak secara vertikal menjadi tegak setelah melakukan tahapan ini.

\section{Pendeteksian Mulut, Hidung, dan Mata}

Pendeteksian elemen wajah yang meliputi mulut, hidung, dan mata akan dilakukan setelah proses preprocessing selesai. Pendeteksian mulut, hidung, dan mata ini dilakukan secara otomatis dengan menggunakan algoritma Viola-Jones.

Setelah proses pendeteksian elemen wajah berjalan dengan baik maka elemen-elemen wajah yang terdeteksi tersebut 
dilakukan proses pemotongan citra sehingga menghasilkan tiga citra masing-masing untuk bagian mulut, hidung, dan mata. Masing-masing bagian mulut, hidung, dan mata untuk setiap citra akan dinormalisasi dengan me-resize ukuran masingmasing bagian. Bagian mulut dibentuk menjadi berukuran 40x60 piksel. Kemudian bagian hidung menjadi 30x40 piksel. Terakhir, bagian mata dinormalisasikan menjadi berukuran 20x60 piksel.

\section{E. Image Enchancement}

Image enchancement diterapkan terhadap bagian-bagian wajah yang telah ditemukan sebelumnya pada tahapan pendeteksian mulut, hidung, dan mata. Tahapan image enchancement ini dilakukan agar citra yang dihasilkan semakin baik dari tingkat kecerahan citra untuk mempermudah proses klasifikasi. Proses image enchancement pertama yang diterapkan adalah mengubah input citra RBG menjadi dalam bentuk grayscale. Tahapan ini untuk menyeragamkan intensitas warna untuk masing-masing citra. Selanjutnya, tahapan kedua yaitu citra yang sudah dalam bentuk grayscale ditingkatkan tingkat kecerahannya dengan meng-adjust contrast citra tersebut. Perhatikan Gambar 7 yang menjalankan tahapan image enchancement citra pada bagian mulut.

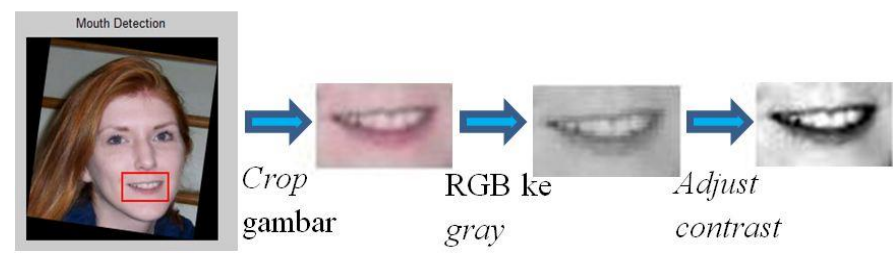

Gambar 7. Visualisasi deteksi mulut dan image enhancement

\section{F. Proses Klasifikasi}

Permasalahan pendeteksian senyum dapat dikategorikan sebagai permasalahan pengklasifikasian yaitu dengan mengklasifikasikan suatu citra ke dalam kelas senyum atau tidak senyum. Proses pengklasifikasian menggunakan classifier Support Vector Machine (SVM) fungsi kernel linear dengan menggunakan fitur vektor yang berasal dari Gabor dan HOG.

Proses klasifikasi dibagi menjadi dua bagian. Pertama, proses klasifikasi menggunakan satu macam bagian wajah seperti mulut saja, hidung saja, mata saja, dan proses klasifikasi menggunakan kombinasi ketiga bagian tersebut. Sebelumnya, dataset telah dibagi menjadi tiga jenis yaitu training, validation, dan testing. Pada klasifikasi yang menggunakan satu macam bagian wajah, dataset yang digunakan hanya training dan testing, training sebagai data pelatihan dan testing sebagai data pengujian. Pada proses klasifikasi ini, dataset validation tidak digunakan. Pengukuran akurasi dari klasifikasi untuk bagian ini dengan melakukan cross validation.

Kedua, proses klasifikasi tersebut menggunakan kombinasi elemen wajah. Pada pengklasifikasian ini, dataset training, validation, dan testing digunakan. Dataset training digunakan untuk pelatihan, dataset validation digunakan untuk memperbaiki classifier yang sudah didapat pada tahap training sehingga terdapat layer baru untuk pengklasifikasian (lihat Gambar 9), dan dataset training digunakan untuk pengujian.

\section{RESULT}

Hasil klasifikasi disajikan dalam bentuk presentase akurasi proses pendeteksian senyum. Akurasi dihitung dengan menggunakan confussion matrix yaitu:

$$
\text { Akurasi }=\frac{T P+F P}{T N+F N+T P+F P} \times 100 \%
$$

Dengan TP (true positive) merupakan citra memiliki label senyum dideteksi sebagai senyum, FP (false positive) merupakan citra tidak senyum dideteksi senyum, TN (true negative) merupakan citra tidak senyum dan dideteksi tidak senyum, dan FN (false negative) merupakan citra senyum namun dideteksi sebagai tidak senyum.

Eksperimen dilakukan dengan menggunakan fitur Gabor, HOG dan gabungan HOG dan Gabor. Fitur untuk masingmasing bagian didapat dengan menjalankan ekstraksi fitur untuk bagian tersebut yang telah dilakukan pada tahapan sebelumnya (preprocessing citra, pendeteksian mulut, hidung, dan mata, dan image enchancement). Untuk fitur gabungan HOG dan Gabor dilakukan dengan cara, misalkan fitur HOG menghasikan vektor $\mathrm{X}=\left\{\mathrm{X}_{1}, \mathrm{X}_{2}, \ldots, \mathrm{X}_{\mathrm{N}}\right\}$ dan fitur Gabor menghasilkan vektor $\mathrm{Y}=\left\{\mathrm{Y}_{1}, \mathrm{Y}_{2}, \ldots, \mathrm{Y}_{\mathrm{M}}\right\}$ dengan $\mathrm{N}$ merupakan panjang fitur $\mathrm{HOG}$ dan $\mathrm{M}$ merupakan panjang fitur Gabor akan menghasilkan vektor baru yaitu $\mathrm{Z}=\left\{\mathrm{X}_{1}, \mathrm{X}_{2}, \ldots\right.$, $\left.\mathrm{X}_{\mathrm{N}}, \mathrm{Y}_{1}{ }^{*}, \mathrm{Y}_{2}{ }^{*}, \ldots, \mathrm{Y}_{\mathrm{M}}{ }^{*}\right\}$ dengan panjang $\mathrm{N}+\mathrm{M}$. Tanda * pada fitur Gabor merupakan hasil dari proses normalisasi. Penormalisasian ini dilakukan untuk menghindari agar suatu fitur tidak dominan terhadap fitur lain. Fitur HOG berada pada rentang 0 hingga 1 dan fitur Gabor pada penelitian ini berada pada rentang -5 hingga 5 sehingga perlu dilakukan normalisasi pada fitur Gabor dengan menjumlahkan 5 lalu membagi dengan 10. Sebagai contoh nilai dari $\mathrm{Y}_{1}$ akan berubah menjadi $\mathrm{Y}_{\mathrm{i}}^{*}=\left(\mathrm{Y}_{\mathrm{i}}+5\right) / 10$. Hasil yang didapat ditampilkan pada Table I.

TABLE I. HASIL KLASIFIKASI DENGAN MENGGUNAKAN FITUR HOG, GABOR, DAN HOG+GABOR

\begin{tabular}{|l|c|c|c|}
\hline \multirow{2}{*}{\multicolumn{1}{|c|}{ Fitur\Akurasi }} & \multicolumn{3}{|c|}{ Akurasi } \\
\cline { 2 - 4 } & Mulut & Hidung & Mata \\
\hline Fitur HOG & $85.60 \%$ & $75.53 \%$ & $67.25 \%$ \\
\hline Fitur Gabor & $88.67 \%$ & $76.60 \%$ & $65.91 \%$ \\
\hline Fitur HOG+Gabor & $90.40 \%$ & $79.68 \%$ & $70.86 \%$ \\
\hline
\end{tabular}

Pada eksperimen tersebut hasil yang didapat tidak sempurna dikarenakan terdapat kesalahan saat melakukan pendeteksian mulut, hidung, dan mata. Contoh citra yang terdapat beberapa kesalahan pada saat pendeteksian bagian wajah tersebut diperlihatkan pada Gambar 8. Kesalahan pada bagian mulut dan hidung umumnya karena kesalahan pendeteksian, namun untuk bagian mata kesalahan utamanya adalah kurang besarnya persegi panjang yang meng-cover daerah mata sehingga tidak seluruh bagian mata terambil. 

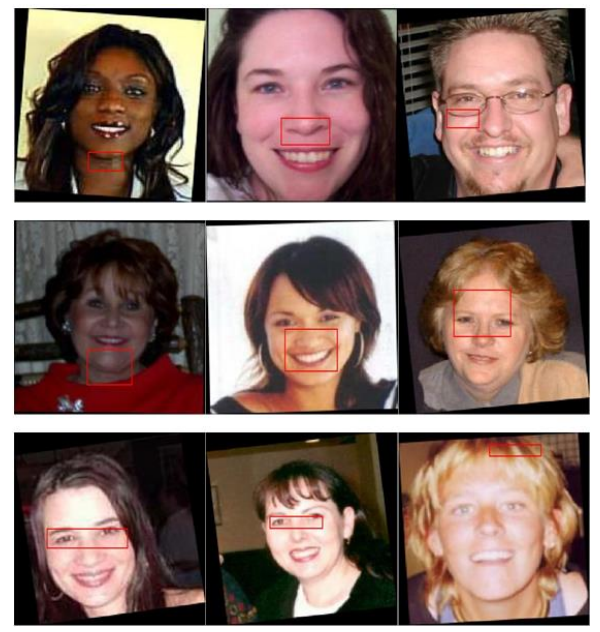

Gambar 8. Baris pertama: kesalahan deteksi mulut, baris kedua: kesalahan deteksi hidung, baris ketiga: kesalahan deteksi mata

Eksperimen selanjutnya menjalankan percobaan dengan menggunakan fitur dengan rata-rata nilai terbaik untuk nilai akurasi bagian mulut, hidung, dan mata yaitu fitur $\mathrm{HOG}+$ Gabor. Kemudian fitur $\mathrm{HOG}+$ Gabor digunakan untuk mengklasifikasikan data testing namun sebelumnya menggunakan dataset validation untuk membentuk decision maker (ensemble learning) dari kombinasi bagian mulut, hidung, dan mata. Bagan proses validasi yang dilakukan sebelum proses testing ditampilkan pada Gambar 9.

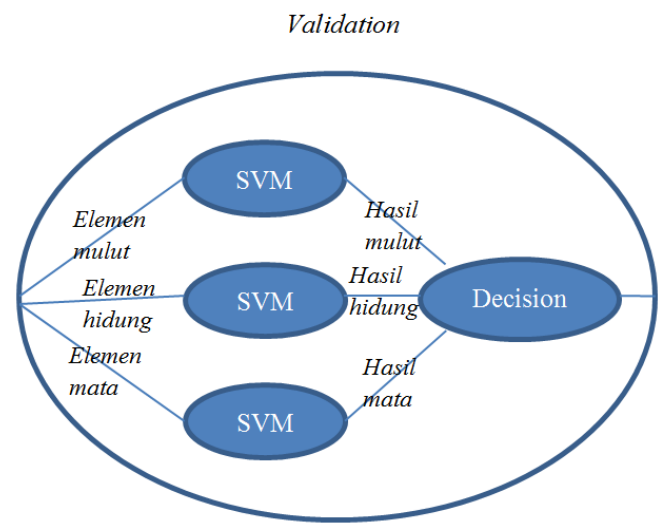

Gambar 9. Ilustrasi tahapan validation

Pada tahap validation ini setiap bagian diklasifikasikan menurut fitur HOG+Gabor, selanjutnya untuk membuat keputusan dari kombinasi hasil bagian tersebut dibuat layer baru. Layer baru tersebut bertujuan menghasilkan keputusan yang optimal, sebagai contoh jika bagian mulut diklasifikasikan sebagai 1 (senyum) dan bagian hidung sebagai 0 (tidak senyum) maka akan diambil keputusan dari mulut 1 dan hidung 0 ke dalam kelas 0 atau 1 dengan melihat kelas mana yang memaksimalkan nilai dari kemungkinan kombinasi hidung dan mata tersebut. Misalkan keputusan optimal konfigurasi mulut 1 dan hidung 0 adalah 1 (senyum) maka citra tersebut akan diklasifikasikan ke dalam kelas 1 (senyum). Keputusan optimal ini menggunakan majority voting.
Tabel II memperlihatkan hasil yang dicapai fitur HOG+Gabor menggunakan bagian-bagian wajah yang dideteksi pada citra.

TABLE II. HASIL KLASIFIKASI MENGGUNAKAN KOMBINASI BAGIAN MULUT, HIDUNG, DAN MATA MENGGUNAKAN FITUR $\mathrm{HOG}+\mathrm{GABOR}$

\begin{tabular}{|c|c|c|c|c|}
\hline \multirow{2}{*}{ Fitur\Akurasi } & \multicolumn{4}{|c|}{ Akurasi } \\
\cline { 2 - 5 } & $\begin{array}{c}\text { Mulut } \\
\text { Hidung }\end{array}$ & $\begin{array}{c}\text { Mulut } \\
\text { Mata }\end{array}$ & $\begin{array}{c}\text { Mata } \\
\text { Hidung }\end{array}$ & $\begin{array}{c}\text { Mulut } \\
\text { Hidung } \\
\text { Mata }\end{array}$ \\
\hline Fitur HOG+Gabor & $90.40 \%$ & $90.40 \%$ & $81.60 \%$ & $90.40 \%$ \\
\hline
\end{tabular}

\section{DETEKSI TINGKAT KeSENANGAN}

Penulis melakukan identifikasi terhadap citra yang terdiri atas beberapa wajah untuk selanjutnya dilihat apakah wajah yang berada pada citra tersebut gembira atau tidak. Penulis melakukan eksperimen terhadap citra yang terdiri atas minimal 3 wajah dengan menggunakan citra dari film Harry Potter dan citra banyak wajah lain guna melihat apakah hasil pelatihan dengan menggunakan dataset sebelumnya dapat digunakan untuk mendeteksi tingkat kesenangan suatu citra di dunia nyata.

Pada tahap ini, untuk dapat melakukan pendeteksian senyum, sebelumnya harus dilakukan pendeteksian wajah terlebih dahulu dengan menggunakan algoritma Viola-Jones. Kemudian, masing-masing wajah yang ditemukan dilihat apakah wajah pada citra tersebut tersenyum atau tidak menggunakan model classifier pada tahap sebelumnya. Setiap wajah yang ditemukan akan diklasifikasikan ke dalam senyum atau tidak senyum. Penulis menggunakan rate untuk menentukan tingkat kesenangan citra tersebut. Rate di hitung sebagai:

$$
\text { Rate }=\frac{N_{\text {senyum }}}{N_{\text {senyum }}+N_{\text {tidak senyum }}} \times 100 \%
$$

$\mathrm{N}_{\text {senyum }}$ merupakan banyaknya wajah yang terdeteksi senyum dan begitupula sebaliknya dengan $\mathrm{N}_{\text {tidak }}$ senyum. Kemudian hasil akan dibagi menjadi tiga kategori yaitu bahagia, sedang, dan tidak bahagia. Hasil itu ditentukan dari nilai rate menggunakan suatu threshold. Jika rate lebih besar dari $60 \%$ maka citra dapat diklasifikasikan ke dalam kategori bahagia, jika rate kurang dari 30\% maka citra diklasifikasikan ke dalam kategori tidak bahagia, dan terakhir jika rate berada pada rentang $30 \%$ - $60 \%$ citra diklasifikasikan ke dalam kategori sedang.

Eksperimen ini dijalankan pada citra yang ditampilkan di Gambar $10^{3}$. Pada pendeteksian ini fitur yang digunakan adalah HOG+Gabor dengan hanya menggunakan bagian mulut pada wajah. Berdasarkan hasil yang diperoleh, pendeteksi senyum yang dikembangkan dapat digunakan untuk melihat tingkat kesenangan lebih dari satu wajah yang berada dalam suatu citra. Hasil yang didapat disajikan pada Tabel III.

\footnotetext{
${ }^{3}$ Harry Potter \& Citra banyak wajah lain
} 


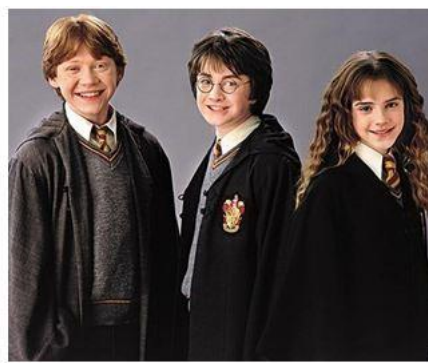

(a)

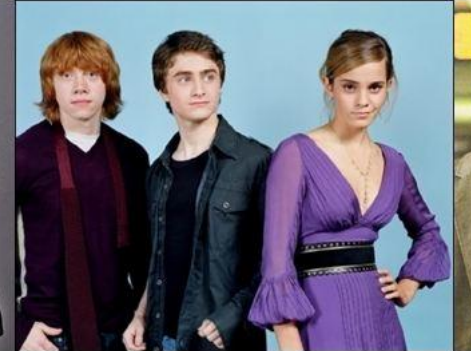

(b)

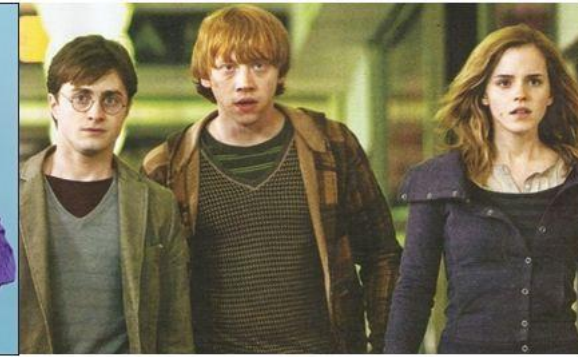

(c)

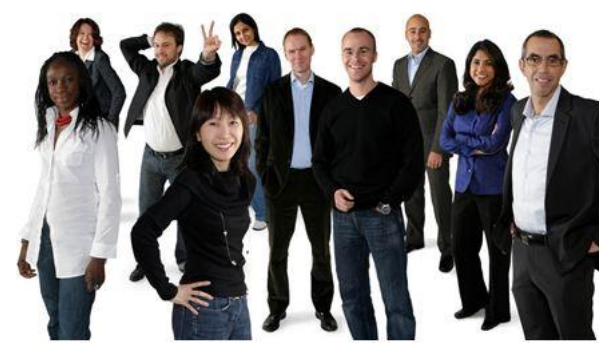

(d)

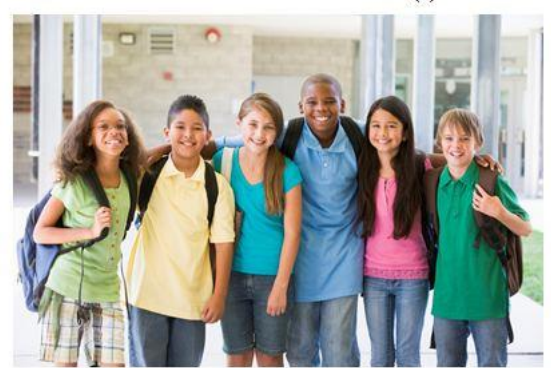

(e)

Gambar 10. Citra dengan banyak wajah lebih dari satu

TABLE III. HASIL KLASIFIKASI PADA CITRA YANG MEMILIKI LEBIH DARI SATU WAJAH MENGGUNAKAN FITUR HOG+GABOR DENGAN BAGIAN MULUT

\begin{tabular}{|l|c|c|c|c|}
\hline \multicolumn{1}{|c|}{ CitralAkurasi } & Senyum & Tidak & Rate & Kategori \\
\hline Gambar 10 (a) & 3 & 0 & $100 \%$ & Bahagia \\
\hline Gambar 10 (b) & 1 & 2 & $33 \%$ & Sedang \\
\hline Gambar 10 (c) & 0 & 3 & $0 \%$ & Tidak Bahagia \\
\hline Gambar 10 (d) & 8 & 0 & $100 \%$ & Bahagia \\
\hline Gambar 10 (e) & 6 & 0 & $100 \%$ & Bahagia \\
\hline
\end{tabular}

\section{SUMMARY}

Fitur tekstur seperti Gabor dan HOG dapat digunakan untuk melakukan pendeteksian senyum pada suatu citra. Tingkat akurasi yang dihasilkan juga terbilang baik yaitu $90.40 \%$. Selain itu, pendeteksian senyum menggunakan bagian wajah yaitu mulut, hidung, dan mata sangat berguna untuk citra yang memiliki lebih dari satu wajah manusia. Dengan menggunakan bagian-bagian wajah, maka dapat dideteksi banyak orang yang ada dan kemudian melakukan pengklasifikasian terhadap ekspresi yang didapat pada masingmasing wajah. Walaupun tidak sempurna, namun secara keseluruhan, pendeteksi senyum ini dapat digunakan untuk mengukur tingkat kesenangan orang pada suatu citra.

Kesimpulan lain yang diperoleh berdasarkan hasil yang didapat pada Tabel I dan Tabel II adalah tidak terdapat peningkatan untuk akurasi jika menggunakan kombinasi yang melibatkan mulut. Hal ini menyimpulkan bahwa mulut merupakan bagian yang dominan terhadap pendeteksi senyum dan dataset validation tidak menjadi keharusan jika menggunakan bagian ini. Namun, bagian wajah lain seperti mata dan hidung jika dikombinasikan (fusion) dan menggunakan dataset validation sebagai sarana untuk memperbaiki classifier maka hal ini dapat meningkatkan akurasi yang sebelumnya berkisar antara 65\% - 79\% menjadi 81.60\%. Dengan kata lain, bagian tidak dominan dari wajah jika dikombinasikan dengan bagian tidak dominan lain dapat menghasilkan pembeda yang baik untuk pendeteksi senyum daripada keduanya berdiri secara terpisah.

\section{REFERENCES}

[1] Whitehill, Jacob, et al. "Toward practical smile detection." Pattern Analysis and Machine Intelligence, IEEE Transactions on 31.11 (2009): 2106-2111.

[2] Bai, Yang, et al. "A novel feature extraction method using pyramid histogram of orientation gradients for smile recognition." Image Processing (ICIP), 2009 16th IEEE International Conference on. IEEE, 2009.

[3] Shan, Caifeng. "Smile detection by boosting pixel differences." Image Processing, IEEE Transactions on 21.1 (2012): 431-436.

[4] Whitehill, Jacob, et al. "Developing a practical smile detector." Proc. IEEE Int. Conf. Automatic Face and Gesture Recognition. 2008.

[5] Zhu, Qiang, et al. "Fast human detection using a cascade of histograms of oriented gradients." Computer Vision and Pattern Recognition, 2006 IEEE Computer Society Conference on. Vol. 2. IEEE, 2006.

[6] http://mplab.ucsd.edu, The MPLab GENKI Database, GENKI$4 \mathrm{~K}$ Subset.

[7] Tsai, Grace. "Histogram of oriented gradients." University of Michigan (2010).

[8] Liu, Chengjun, and Harry Wechsler. "Independent component analysis of Gabor features for face recognition." Neural Networks, IEEE Transactions on 14.4 (2003): 919-928 